\title{
THE 'AMERICAN' HEGEMONIC CULTURE: ITS ROOTS, FEATURES AND IMPLICATIONS TO WORLD CULTURE
}

\author{
Kasiyarno* \\ Ahmad Dahlan University Yogyakarta \\ kasi_uad@gmail.com
}

\begin{abstract}
That America is historically a nation which developed a hegemonic culture around the world has been an unquestionable issue for many Americanists. In that kind of culture, it insisted that the world had no alternative but acceptance of American ideas, values and way of life. This is what we call as Americanization which drives a cultural imperialism through eagerly practicing the hegemonic culture primarily when the country rose as the single world hegemon. It is really factual that American hegemonic culture is the cultural heritage from British Empire, which had already got a strong influence from Roman Empire. Because of the strong myth as the chosen people, the United States is clearly identified as a strong expansionist which always tries to control others and acts unilateraly. Through this way, the United States promotes itself as the most influential country and its culture as the most widely imitated around the world.
\end{abstract}

Keywords: Hegemonic Culture, Americanization, Expansionist, the Most Influential

\section{INTRODUCTION}

In Gramsci's theory of hegemony, the hegemony is a concept that may explain at least two things: firstly, how the apparatus of the state or a political society can lead strongly the various strata of society to accept the status quo, through legal institutions, the police, soldiers and prisoners, secondly, and this is more significant to this paper, how and where the political society, as well as civil society, with all its institutions at their disposal, ranging from educational institutions, religions, and family up to the production of meaning and value of the product, directing and confirming agreement forms 'spontaneously' various strata of society with the status quo (Holub, 1992, p.5).
In the matters of cultural practices, Gramsci has not only highlighted the cultural aspects of consumption or reception only, but also investigated the importance of the cultural production or how they are produced. Gramsci's analysis of hegemonic cultural production explained that the organization provides material of hegemonic structures while ensuring a large space for the development of popular culture. For the sake of this research, the word 'hegemony' is a much more appropriate term than 'empire', as it is noted that the U.S. foreign policies tend to describe generally the historic U.S. relationship with other countries that emphasize the existence of a consensus based on the rules, the values and institutions arranged by the U.S., and also the possibility of violence but not for the purpose of the 
occupation of territory (Agnew, 2005, \& Beeson, 2003). Meanwhile, "America" is a category with particularizing effects that are as central to how we think about the possibilities and limitations of the field of American studies as the universalizing term "culture" is to our understanding of the shape of the field of cultural studies (Burgett and Hendler, 2007, p.4).

Because of the U.S. strong position in the international arena, in a review of the New American Studies, the notion of 'America' is no longer understood only as a country that runs the political isolation, but rather a network of cultural influence extended beyond its hemisphere since the period of colonization to the present (Levander, 2009, p.28). It suggests that 'America' is a huge area of cultural influence globally to all nations and countries in the world. It also implies that American Studies should focus on the hegemonic culture to explain the how and why America develops its hegemonic culture, as Gruesz (Gruesz, 2007, p.20) said," America has generally been used as a term of consolidation, homogenization, and unification."

On this paper, the hegemonic culture is defined as a set of values, beliefs, ideas and cultural practices that are always willing to dominate, defeat and manage other cultures that are within the circle of power culture. This meaning relates to and is based upon the new perspective of American Studies, which are new parameters developed to critically explore US culture and discuss the role of America in a changing world order (Fluck, Brandt, and Thaler, 2007, p.1). This paper puts three big questions: Where does the American hegemonic culture come from? What are the features of the hegemonic culture? What are its implications to the world culture? These questions need to be answered and enshrined in many discussions on the American hegemonic culture and its implications to the world culture.

\section{THE ROOTS OF 'AMERICAN' HEGEMONIC CULTURE}

The question about the source of the current U.S. hegemony becomes critical in understanding the hegemonic culture; the search for the answer to this question even has quite dominated the discourse and the scientific works in the field of American Studies. In general, there are three options for the answer of the questions: (a) it comes as an imperial heritage of the United Kingdom; (b) it comes from the western European ancestors; and (c) it is the American specific national culture. In specific, the root of this hegemonic culture had been from the Romans culture.

The theory that the U.S. hegemonic cultural roots originate from the imperial heritage of the United Kingdom was proposed by Russell Kirk (Kirk, 1993) in his book 'America's British Culture'. He states that the United 
Kingdom is a country regarded as the ancestral land of the modern American nation, so that when the elements of British culture cleaned of all cultural patterns in the United States, then surely the American people will lose their own cultural values. With this understanding, the United States is currently worth mentioning as an heir to the throne of Imperial Kingdom of Great Britain (Ferguson, 2004, \& Garrison, 2004), without having to go through war to seize the throne (Garrison, 2004, p.74-76), so it can be said that the 20th century is "a century-born U.S. hegemony and empire".

The next view reveals that the American people forever are the Western European. It is based on the history of the conquest of the Americas by the British Americans. This view can be traced from Madison Grant's The Conquest of the Continent and Ales Hrdlicka's seminal work entitled Old Americans. Madison Grant said: "It is probably accurate to say that there never has been a nation which was so completely and definitely Protestant as well as Nordic as was the United States just after the American Revolution." On the final pages of The Racial Origins of the Founders of America, Ales Hrdlicka characterized Old Americans as individuals whose ancestors arrived prior to the wars between the States (Peterson, 1995). In addition, the majority of Americans can trace their family to at least one ancestor who lived in Western Europe.

Both opinions are then summed up by Joseph Fallon (Fallon, 1995, p.150) who said that the
United States has a specific national culture, although in fact it is essentially the English culture through the modification by their wild nature. American culture is said to be specific because it is a configuration of ways and means used by the American people to express a collective sense of self (Kroes, 1999, p.465), and this culture remains imperialistic nation since it confirmed the presence of a comparable nature with the nature of Roman imperial power (Ibid, 1999, see also: Garrison, 2004, p.4). The U.S. imperial power inherited from the United Kingdom has been implementing global hegemony across the world as well as the basis for the determination of foreign policy (Mead, 2002, p.125 \& Garrison, 2004, p.76).

The uniqueness of American culture is also seen in the implementation of foreign policy, especially after it inherited 'the mantle of global hegemony', which actually fought over by various countries through World War II. Bradley (Bradley \& Lubis, 1991, p.xvi-xvii) said that the U.S. politically applies dualbranch with a number of conflicting characteristics. The United States combines a realistic-practical with the idealistic-utopian. On the one hand, its foreign policy is directed to protect and extend the benefit to U.S. commercial interests around the world, while on the other hand, it has an ideal to become a superpower that capable of building an international system, and as far as possible in the manner and according to its will and own interpretation, so it will bring a flat, globalized world (Kroenig \& Ratner, 2007), under the 
leadership of a single superpower, accompanied by expanding ideology as illustrated by Garrison (Garrison, 2004, p.80) as follows:

The essential reason for the success of American foreign policy is that, following Britain, the United States has been motivated fundamentally by resources and trade, not territory. ... money, not land, has always been at the core of American imperial designs. Integral to its imperial strategy has been the mission of spreading democracy and human rights around the world.

From what Garrison mentioned above, it can be understood also that in establishing its hegemony, the U.S. has different ways from European countries which mostly use the political power in the occupied territories. The United States is widely known to have antiimperialist sentiments; but in fact, it also applies the methods of imperialism. The United States does not engage in direct imperialism or colonial territory, and even has anti-imperialism as it has been pointed out since the Cold War era with decolonization policy. However, in practice, as a country that embraces the ideology of capitalism, the U.S. paradigm cannot be completely separated from the imperial strategy of development effort (Garrison, 2004). Veriyawan (Veriyawan, 2007) also said that the ideology of capitalism is not only the basis for the development of the economic system (capitalism or neo-liberalism), but also as a basis to build its foreign policy. Colonization or imperialism is used as its method in the foreign policy, though not directly. By using a unique and aggressive foreign policy over the past two centuries, the U.S. has managed to establish its global hegemony (Garrison, 2004, p.57).

Most notably, the uniqueness of American culture that can be traced in the differences between American and Western European values as surveyed by the Pew Research Center in 2011 are as follows: (1) Americans are more individualistic and are less supportive of a strong safety net than are the publics of Britain, France, Germany and Spain, (2) Americans are also considerably more religious than Western Europeans, and are more socially conservative with respect to homosexuality, (3) Americans are somewhat more inclined than Western Europeans to say that it is sometimes necessary to use military force to maintain order in the world.

Above all, there are some astonishing similarities between the rise of the American state and power and the upsurge of Roman Republic. Tsonchev (Tsonchev, 2012) wrote, "These likenesses are not due to the specific character of both states, rather there is a common pattern in the development of every powerful state and the U.S. and Rome are examples of this pattern." These common patterns are the evidence or the strong indicators that the American hegemonic culture has a root in the Romans culture. We can trace the Roman hegemonic culture from 
the history fact in which the Romans produced a great civilization to the world. No wonder if the Americans have used many Romans myth as expressed in values, norms and even buildings and statues.

\section{The Features of 'American' Hegemonic}

\section{Culture}

Traditionally, Americans have struggled for their lives based on the American dreams of success, fame and wealth through thrift and hard work. In brief, the American dream is a myth that, in America, opportunity exists for reward that is directly commensurate with one's effort. The inspiration of American Dream has come long before the independence of United States was declared, dating back to the $16^{\text {th }}$ century, when people began to share hopes and aspirations for the new and largely unexplored continent (Smith, 2012). As Freese (Freese, 1985, p.78) says 'Long before 'America' became a country, it was a continent, and long before it was known to exist as a continent, it was a vision and a dream.'

Boorstin (Boorstin, 1962, p.239-240) illustrated America on his book: "America has been a land of dreams. A land where the aspirations of people from countries cluttered with rich, cumbersome, aristocratic, ideological pasts can reach for what once seemed unattainable. Here they have tried to make dreams come true."
The image of the America has clarified the existence of the so-called 'the American Mind'(Wise, 1979, p.179) - a term taken from the title of Williams and Gabriel's book in 1937 about the American thought and civilization, the idea of soul or character typical of Americans who have great expectations (hopeful), net of bad temperament (innocent), keep freedom and personal rights (individualistic), give priority to the principle of expediency and practical (pragmatic) and own a goal-major goal to build the civilization of the world (idealistic). Thus, the American Mind may be considered as "a testament to the height of the nation's culture and American countries". The American Mind can be traced since 1900, when Senator Albert J. Beveridge announced his conviction that God has established the nation-American as His chosen people to inherit the leadership that saved the world. To be able to carry out the mission of the American people, Beveridge brought together world religious themes, politics, economics, history and psychology to the issue of a new imperialism (Judis, 2004, p.14).

The hegemonic culture has also been empowered by the concept of 'American exceptionalism'.

The term exceptionalism was coined to describe the ideology of a promised land and a chosen people (Fluck, 2007, p.60). American exceptionalism and the manifest destiny image are at the heart of any understanding of United 
States imperialism/empire (Grondin, 2006, p.10). It can be classified into two types: (a) substantive exceptionalism, which is the study of exceptionalism in terms of actual outcomes and the actual doctrines, and (b) methodological exceptionalism, namely the study of exceptionalism in terms of methods and approaches. In its actualization, Michael Ignatieff (Ignatieff, 2005, p.3-8) divides American exceptionalism into three different faces, namely:

(1) American exemptionalism (arbitrariness of America to not comply with the rule of law and international treaties unilaterally);2) double standard (using a different measurement standard between himself and other countries; between friendly countries with a country that does not like), 3) legal isolationism (interpretation of the law and justice unilaterally by the United States) (Schauer, 2005, p.30-31).

By looking at the division of American exceptionalism by Michael Ignatieff, the actual understanding of exceptionalism is not relevant when associated with the label of America as a country striving for democracy, - in fact, Americans use double standards in formulating and practicing democracy, but rather as a good luck in history due to its ability to be a rich nation from human and natural resources and its success in winning the two and its success in winning two World Wars and the Cold War, as written by Hodson (Hodson, 2009, p.157-158):
In the Twentieth Century, America was exceptional not so much for a commitment to democratic ideals but for two other reasons. For one thing, the United States became exceptionally rich, partly because of its natural and human resources, but also because, unlike its European rivals, it was not devastated and impoverished but was enriched by two world wars.

American exceptionalism has also been used for insulation, which is a policy to isolate, and supervise all gestures or the leader of another nation in violation of democracy and human rights according to the standard one-sided American. Politic is the result of the foreign policies priority that run the U.S. role as a 'world's policeman'. Feeling as the global cop, said Jiemin (Jiemin, 2005), the U.S. has never wanted to hear any voices or criticisms of other nations or other groups who disagree with U.S. foreign policy practice. In other words, all the countries of the world must be willing to accept and follow American will; while whoever against the U.S. interests, culture, or world view would be seen as a threat to human life and serve the common enemy (Sardar \& Davies, 2004, p.64-65, \& Soderberg, 2005). This foreign policy based on U.S. leadership perpetuates and encourages the myth that the United States can and should manage the rest of the world (Conry, 1997).

\section{THE IMPLICATIONS TO WORLD}




\section{CULTURE}

The world history records that the American hegemonic culture has occupied since the occupation of the American continent itself. In the early phase, the conqueror of the continental have killed almost $97 \%$ of the $4-9$ million indigenous people who have been first occupied this region. This phase can be termed as the era of colonialism as an obvious evident in the practice of American hegemony. Through the Monroe Doctrine in 1823, the hegemonic practice expanded to American hemisphere regions, including Central America to the Caribbean islands and a number of islands in the Pacific region, even to the country Philippines. This period was also marked by the rise of the corporate capitalism where businesses in agriculture and bank loans monopolized various concessions in large quantities overseas. In the next phase, in the 1970s, a new style of American hegemony took advantage of global control over a wide range of economic regulation through the post-World War II Bretton Woods system, but this strategy got opposition or challenges from Europe and Japan. As a result, America changed strategy of expanding its power of virtual forms of colonialism into the form of hegemony to the world culture.

The implications of the American hegemonic culture to the World culture have been analyzed in many ways. It has created an Americanization which dominated all aspects of life in the whole world. In the early 1900 's, "Americanization" referred to the movement where immigrants were urbanized into Americans (Huebner, 1906, p.191). Now, in today's world, the term has a different, but similar meaning - the globalization by the U.S. of the world. Henry R. Luce in writing an editorial in Life magazine (17 February 1941) has been called the era of U.S. dominance in the term of the American Century.

The term is intended to describe the emergence of the United States in the international arena as the greatest power, or a pax Americana (Hodson, 2000, p.118, \& DeConde, Burns, and Logevall, 2002, p.495). The Luce's editorial has encouraged Americans to accept their destiny and use influence to remake the world according to their own values (Hogan, 1999, p.1). It has confirmed the U.S. image as a nation that is as strong as imperialistic Rome in the reign of the Roman Empire (Kroes, 1999, p.465).

A strong majority thinks US culture had a lot of impact on other countries in the 20th century, and an overwhelming majority believes it will have equal or greater influence in the 21 st century. The American victories experience achieved in various battles in the global scale, both physically and ideology, - it has undermined the spread of the ideology of Fascism at World War II, and the ideology of communism in the Cold War -, has encouraged greatly the growth of American awareness and confidence so that the Americans truly believe that they have a superior and privileged nation. Based upon that special feeling, it is no wonder the U.S. 
later perceives the world in the eyes of America itself, thus encouraging the process of so-called Americanization of culture, as written by Jiantao (Jiantao 2007, p.39):

After the World War I, especially after World War II, with the unprecedented development of American economy, the abundant supply of material goods prompted the rise of the popular culture based on the consumption and entertainment, and since then Americanization has been used to describe the process of American popular culture influencing, reshaping other countries' culture and the latter's converging to the former.

In the global hegemonic culture, the values, consumption patterns and the Western way of life spread around the world through a number of strongly influential channels of globalization (for example: trade, tourism, cultural exchanges, print and electronic mass media, a partnership or alliance ). This process is believed to bring the impact of changes in mindset and culture of social life resulting in homogenization of the world, a flat, globalized world (Kroenig \& Ratner, 2007). Thus globalization has become a very powerful weapon to force poor countries and developing into the range of cultures, markets and power of America (Mishkin, 2006, p.131). In other words the process of globalization can be identified as the process of Americanization effort.
One phenomenon of globalization which brings culturally resonant and getting lots of attention from the public, activists, observers and experts of culture is what is called 'the McDonald-ization', an idea that is considered to describe many things ranging from religion, the university and museums. The McDonaldization clearly brought new cultural values for the nations of Asia, especially on the model of business organization, style of consumption and consumerism. This happens because the McDonaldization is the process by which the principles of fast-food restaurant comes to dominate more sectors of American society and world society (Ritzer, 1996, p.1), and because fast food, style of dress, entertainment, and the language of the West brought hidden cultural communication about values which are considered more important in the aspect of morality, identity and life (Marsella, 2005, p.3).

It is obvious then that the globalization today is American-centric; in that much of the information revolution comes from the United States, and a large part of the content of global information networks is currently created in the United States and enhances American 'soft power' (Nye, 2007, p.170). Globalization has indeed been used extensively by the United States for the benefit of the future of the nation itself, the power to expand and maintain the empire (Garrison, 2004, p.39). The phenomenon of globalization has even been seen as an aspect of the nature of imperialism, that is the cultural hegemony of a particular center to further increase the spread 
of values, consumer goods and lifestyles of America (Tomlinson, 1997, p.174). The worldwide spread and dominance of American consumer culture and products, which many nations claim is eroding their local cultural traditions and values and represents a form of global cultural regulation. For instance, in the context of Asia, the cultural globalization deals directly with the Asian values. Thus, the issue of cultural imperialism raises both questions of cultural identity and government policy (Rauschenberger, 2003, p.1-2).

As a result, the cultural hegemony has become a powerful medium to read the power structures between different cultures (Hanafi, 2009, p.139). The use of American hegemonic culture through globalization established the assumption that cultural power is "bigger than the political and economic rule" (Wattenberg, 1991, p.213, quoted by Nye, 2004, p.47). The spread of American culture into the daily life of the global community has led the U.S. into a new form of colonialism, the 'cultural imperialism', so that globalization as an international system has replaced the Cold War, in which the tensions between the U.S. and the Soviet Union ended and replaced with the tension with many other countries in terms of policy and practice its imperialistic culture.

\section{CONCLUSION}

There are three main perspectives about where the American hegemonic culture comes: (a) it was inherited from the United Kingdom; (b) it was developed by the whole western European ancestors; and (c) it originates form of American specific national culture.

The American dream and the American exceptionalism are the main features of the hegemonic culture since both of them have been occupied by and familiar among American people since the very early of American history.

The two myths have been internalized in the mind of American so that it is reasonable if they also are reflected in American foreign policies for establishing a new international political order and a new international economical order based on its own interests.

It is recognized that the power of culture has been greater than the political and economic rules. As the changes of the world political situation in the post Cold War era, the United States attempted to unify the world with its cultural values in order to gain its success that cannot be reached through military force. The implication to the world culture is very obvious, that is the changes of other cultures to be Americanized. The global public, ranging from Austria to Australia, tend to believe that the process of Americanization of American popular culture is a subject, even necessary, before the advent of the success of the United States in the political, military and economic developments in the Cold War.

The American culture is the culture of the most widely imitated around the world while 
what drives the American cultural imperialism is the expansion of foreign markets and the recognition of the greatness of America. The motivation behind the American cultural imperialism runs parallel to the justification of imperialism of the United States throughout history, the desire to gain entrance to foreign markets and the belief in the superior value of American culture.

\section{REFERENCES}

Agnew, J. (2005). Hegemony: The New Shape of Global Power. Philadelphia: Temple Uni versity Press.

Ales, H. (1925). Old Americans. Baltimore: Williams \& Wilkins.

Beeson. (2003). Resisting Hegemony: The sources and limits of anti-Americanism in South east Asia. Paper for the workshop on Globalization, Conflict and Political Regi mes in East and Southeast Asia, (August 15th-16th, 2003), Fremantle, WA.

Boorstin, D.J. (1962). The Image: Or What Happened to the American Dream. New York: Atheneum.

Bradley, W. L. \& Lubis, M. (1991). DokumenDokumen Pilihan tentang Politik Luar Negeri Amerika Serikat dan Asia. Jakarta: Yayasan Obor Indonesia.

Burgett, B, \& Hendler, G. (2007). An Introduction. In: Burgett, Bruce and Hendler, Glenn (eds.). Keywords for American Cultural Studies. New York and London: New York University Press.

Conry, Barbara. (1997). U.S. "Global Leader ship": A Euphemism for World Police man. Cato Policy Analysis, No. 267.

DeConde, A., Burns, R. D. \& Logevall, F. (eds.).
(2002). Encyclopedia of American Foreign Policy: Studies of the Principal Movements and Ideas. New York:

Charles Scribner's Sons.

Fallon, J. (1995). The Roots of American Order. The Social Contract, Winter, 150-151.

Ferguson, N, (2004). Colossus: The Price of America's Empire. New York: The Pinguin Press.

Fluck, Winfried. (2007). Theories of American Culture (and the Transnational Turn in American Studies). REAL: Yearbook of Research in English and American Literature, No. 23, Narr Verlag, Tübingen.

Fluck, W., Brandt, S., and Thaler, I. (2007). Introduction: The Challenges of

Transnational American Studies. REAL: Yearbook of Research in English and American Literature, No. 23, Narr Verlag, Tübingen.

Freese, P. (1985). The American Dream and the American Nightmare: General Aspects and Literary Examples. Anglistik und Englischunterricht, 25 Heidelberg.

Garrison, J. (2004). America as Empire: Global Leader or Rogue Power? First Edition. San Francisco: Berrett Koehler Publishers, Inc.

Grant, M. (1933). The Conquest of a Continent. New York: Charles Scribner's.

Grondin, David. (2006). Introduction: Coming to Terms with America's Liberal Hegemony / Empire. In: David, C. P. \& Grondin, D. (Ed.), Hegemony or Empire?: The Redefinition of US Power under George W. Bush. Hampsire: Ashgate Publishing Group.

Gruesz, K. S. (2007). "America," in Keywords for American Cultural Studies, eds. Bruce B., \& Glenn H. New York and 
London: New York University Press, (2007), 16-22.

Hanafi, S. (2009). Cultural Difference or Cultural Hegemony? Contextualizing the Danish Cartoon Controversy within Migration Spaces. Middle East Journal of Culture and Communication 2, 136152. Leiden: Koninklijke Brill NV.

Hodson, J. (2000). Globalization and National ism in the United States: a Historical Perspective. In: Suryadinata, L. (Ed.), (2000). Nationalism and Globalization: East and West. Singapore: Institute of Southeast Asian Studies.

Hogan, M. J. (Ed.), (1999). The Ambiguous Legacy: U.S. Foreign Relations in the

"American Century", New
York:

Cambridge University Press.

Holub, R. (1992). Antonio Gramsci: Beyond Marxism and Postmodernism. London and New York: Routledge, Inc.

Huebner, Groever G. 1906. The Americanization of the Immigrant. Annuals of the American Academy of Political and Social Science, Vol. 27, 191-213.

Ignatieff, M. (2005). American Exceptionalism and Human Rights. Princeton, New Jersey, 29-56.

Jiantao, H. (2007). Hurricanes from the South: On the Situations and Reasons of Canadian Americanization since World War II, Korean Review of Canadian Studies, South Korea, Vol. 13, 39-67.

Jiemin, G. (2005). Cultural Power and Cultural Conflict, http://www.crvp.org/book/Seri es03/III-20/chapter_iii.htm. Retrieved July 04, 2005.

Judis, J. B. (2004). The Folly of Empire: What
George W. Bush Could Learn From Theodore Roosevelt and Woodrow Wilson. New York: Oxford University Press.

Kirk, R. (1993). America's British Culture. New Brunswick: Transaction Publishers.

Kroenig, M. \& Ratner, A. (2007). How Globalization Went Bad. Foreign Policy. January/February.

Kroes, R. (1999). American Empire and Cultural Imperialism: A View from the Receiving End. Diplomatic History, Vol. 23, No. 3, 463-477. Oxford: Blackwell Publisher.

Levander, C. (2009). The Changing Landscape of American Studies in a Global Era.

Working Together or Apart: Promoting the Next Generation of Digital Scholarship. Washington DC: Council on Library and Information Resources, 27-34.

Luce, H. R. (1941). The American Century. Life. (February, 17 $7^{\text {th }}$ 1941). Daily News Headlines Digest. http://www.inform ationclearinghouse.info/article6139.htm (June $5^{\text {th }} 2010$ ). Retrieved October 11, 2011.

Marsella, A. J. (2005). Hegemonic Globalization and Cultural Diversity. Australian Mosaic Fall. (2005), Issue 11, No. 13, 15-19.

Mead, W. R. (2002). Special Providence: The American Foreign Policy Tradition. New York: Routledge, Inc.

Mishkin, F.S. (2006). The Next Great Globaliza tion: How Disadvantaged Nations Can Harness Their Financial Systems to Get Rich. Princeton: Princeton University Press.

Nye, Jr. J. S. (2007). Culture, Soft Power, and 'Americanization'. In Held, D., Moore, H.L., \& Young, K. (Ed.), Cultural 
Politics in a Global Age: Uncertainty, Solidarity and Innovation. Oxford: One world Publications.

Peterson, R. (1995). The Racial Origins of the Founders of America. Washington, DC: Scott-Townsend.

Pew Research Center, (2011). The AmericanWestern European Values Gap. American

Exceptionalism Subsides. Washington: Pew Global Attitudes Project.

Rauschenberger, E. (2003). It's Only a MovieRight? Deconstructing Cultural Imperial ism: Examining the Mechanisms behind U.S. Domination of the Global Cultural Trade. Retrieved at www.nyu.edu/gsas/

dept/politics/undergrad/research/rausche n berger_thesis.pdf on August 3, 2012.

Ritzer. G. (1996). Sociological Theory. $4^{\text {th }}$ Edition. Singapore: The McGraw-Hill Companies. Inc.

Sardar, Z. and Davies, M. W., (2004). Why Do People Hate America? Cambridge: Icon Books Ltd.

Schauer, F. (2005). The Exceptional First Amendment in American
Exceptionalism and Human Rights.
Michael Ignatieff.

2005. Princeton: New Jersey, 29-56.

Smith, S.E., (2012). What is the "American Dream"? Wise GEEK: clear answers for common questions. Nevada: Conjecture Corporation, Sparks.

Soderberg, N. (2005). The Superpower Myth: the Use and Misuse of American Might. Hoboken. New Jersey: John Wiley \& Sons, Inc.

Tomlinson, J. (1991). Cultural Imperialism: a Critical Introduction. London: Continuum.

Tsonchev, T.S. (2012). Is America The New Rome? The Montreal Review. Canada: Tsonchev Publishing \& Design.

Veriyawan, W. (2007). Politik Luar Negeri Amerika di Indonesia. Jakarta: Universitas Indonesia.

Wattenberg, B. J. (1991). The First Universal Nation: Leading Indicators and ideas about the Surge of America in the 1990s. New York: The Free Press.

Wise, G. (1979). Paradigm Dramas in American Studies: A Cultural and Institutional History of the Movement. American Quarterly, 31, 293-337. The Johns Hopkins University Press. 
